\title{
Meteorolojik Kaynaklı Afetlere Karşı Bir Meydan Okuma: Dirençli Planlama
}

\author{
Sümeyye KAHRAMAN ${ }^{1}$ ve Erkan POLAT $^{2}$
}

\section{Öz}

1970’ten günümüze kadar dünya nüfusu yaklaşık \%87 büyümüştür. Aynı zamanda, nehir havzalarında sele maruz kalan insanların oranının \%114, siklonlara maruz kalan kıyı şeridinin ise \%192 arttığı ve gelecekte daha fazla artacağı öngörülmektedir. Meydana gelen meteorolojik kaynaklı afetlerin büyük bir kısmı daha çok kentsel alanları etkilemekte ve çeşitli riskleri de beraberinde getirmektedir. Kentsel alanlarda yaşayanların yoğunluğu ve altyapıya olan bağımlılık göz önüne alındığında, kentsel alanlar şiddetli fırtınalar, siklonlar, heyelanlar, taşkınlar, çığlar gibi meteorolojik kaynaklı afetlere karşı en duyarlı alanlar olarak görülmektedir.

Planlamada meteorolojik kaynaklı doğal afet risklerinin göz önünde tutulmaması risklerden etkilenebilirliği artırmaktadır. Bir başka ifade ile afetlerin istihdam, konut, enerji, ulaşım, su kaynakları vb. üzerinde daha fazla hasara yol açtığı anlamını da taşımaktadır. Afet yönetiminin, esnekliğin/dayanıklılığın, risklerin ve kırılganlıkların hızla değiştiği kentsel ortamdaki etkisini azaltmak için esnekliğin/dayanıklıığın, risklerin ve kırılganlıkların tespiti önemlidir. Dirençli planlama, afet yönetimini gözeten, afet durumlarıyla başa çıkabilecek, önceden hazırlıklı olabilecek bir yaklaşım sunmaktadır. Bu nedenle, felaketlerin, bir kereye mahsus olduğu yaklaşımı yerine, bölgeleri/kentleri planlarken, riski azaltma ve dayanıklılığı artırma merceğiyle bakılması kritik önem arz etmektedir.

Meteorolojik kaynaklı afetlerin risklerinin/etkilerinin önlenmesinde/azaltılmasında kent ve bölge planlama disiplini dirençli kentler ortaya konulmasında önemli bir araç olarak rol alır. Bu nedenle çalışmada, meteorolojik kaynaklı afetlere karşı dirençli kentleri oluşturmak için kent ve bölge planlama disiplininde mekânsal alanda hangi politika ve önlemler alınması gerektiği üzerinde durulacaktır. Meteorolojik kaynaklı afetlere karşı dirençli kentler adı altında kent ve bölge planlama disiplininde geliştirilen çalışmalar ele alınacak ve yeni öneriler sunulacaktır.

ANAHTAR KELímELER: Afet, Meteoroloji, İklim Değişikliği, Dirençli Planlama, Kent ve Bölge Planlama

\section{An Stance Against to Meteorological Disasters: Resilient Planning}

\begin{abstract}
From 1970 until today the world population has grown by about $87 \%$. At the same time, it is estimated that the percentage of people exposed to floods in the river basins will by increase

\footnotetext{
${ }^{1}$ Doktora Öğrencisi, Mimarlık, Planlama ve Tasarım Anabilim Dalı, Süleyman Demirel Üniversitesi, Isparta, Türkiye.

2 Prof. Dr., Şehir ve Bölge Planlama Bölümü, Süleyman Demirel Üniversitesi, Isparta, Türkiye.

*ilgili yazar / Corresponding author: sumeyyekahraman1994@gmail.com
} 
$114 \%$, the coastline exposed to cyclones will increase by $192 \%$ and will increase further in the future. A large part of the meteorological disasters are mostly affects urban areas and brings various risks. Considering the density of urban residents and the dependence on infrastructure, urban areas are considered to be the most sensitive areas against meteorological disasters such as severe storms, cyclones, massive storms, landslides, floods, avalanches.

In meteorological-based planning, non-consideration of the natural disaster risks increases the influenceability to risks. In other words, it means that disasters cause more damage on employment, housing, energy, transportation, water etc. resources. It is important to identify flexibility/durability, risks and fragility to reduce the impact of disaster management, flexibility/durability, risks and fragility on the urban environment in which it is rapidly changing. Resilient planning provides an approach that can be prepared in advance, which is capable of dealing with disasters, taking into account disaster management. Therefore, instead of a one-off approach to disasters, when planning urbans, it is critical to look at risk reduction and durability enhancement.

Urban and regional planning discipline plays an important role in putting out resistant cities in reducing the risks of meteorological disasters. Therefore, in this study, it will be emphasized which policies and measures should be taken in spatial area in urban and regional planning discipline in order to create cities resilient to meteorological disasters. The studies developed in the discipline of urban and regional planning under the name of meteorological-resilient disasters will be discussed and new proposals will be presented.

KEYWORDS: Disaster, Meteorology, Climate Change, Resilient Planning, Urban and Regional Planning

\section{GíRiş}

\section{Kentler direnç gösterir, bazı kentler dirençlidir, bazı kentler ise dirençsiz.}

Dünyamızın 3/4 'ünü su kaplamakta, vücudumuzun ise \%60'nı. İnsan organizmasının önemli bir kısmı sudan meydana gelmekte, kan dolaşımının olabilmesi, vücudun zararlı maddelerini atabilmesi için su önem teşkil etmektedir. Dünyada nüfus hızla artmakta, buna karşın su kaynakları sabit kalmakta, su intiyacı artmaktadır. Günümüzde dünya nüfusunun \%20'si yeterli içme suyundan mahrum, bir kısmı sağlıklı suya hasretken, 2050 yılında dünya nüfusunun \%50'sinin su sıkıntısı çekeceği öngörülmektedir (United Nations, 2015). Buna rağmen iklim olaylarının hızla değişmesiyle beraber bir tarafta kuraklık ve kıtlık yaşanırken, bir tarafta sel ve afet çelişkisi ortaya çıkmaktadır. Su artık hem hayat hem de ölüm haline gelmiş dualistik bir element olmuştur.

Son yıllarda, birçok kentin artan büyüklüğü ve yayılımı, iklim değişikliğinin boyutlarının da artması genel olarak birçok doğal tehlikenin yıkıcı etkilerini arttırmaktadır (1995-2015 yılları arasında doğal afetlerin meydana gelme yüzdesinde \%43'lük pay sel, \%28'lik pay fırtına olayıdır) (UNISDR\&CRED, 2015; 11,13). Bu eğilimler, yerleşimlerde daha fazla kırılganlığına yol açmakta ve risklerin artmasına neden olmaktadır. Son zamanlarda doğal olayların yol açtığı felaketlerin nedenleri ve eğilimleri ile ilgili yapılan araştırmalarda, yerleşimlerin dirençli olamama durumunun daha fazla etkilenebilirliği arttırdığı gözlenmektedir. Bu nedenle, afetlere hazırlığı artırmak, meydana gelecek olanların da etkilerini azaltmak için uluslararası camiada meteorolojik afetlere karşı dirençli kent yaklaşımlarının gerekliliği üzerinde durulmaktadır. 
Günümüzde dirençlilik kavramı, iklim değişikliği adaptasyonununda, sürdürülebilirlik çalışmalarında, afet riskini azaltmada ve önlemede, yoksulluğu azaltmada ve giderek artan küresel sorunlarla başa çıkmada kullanılmaktadır (OECD, 2018; 9). Özellikle iklim değişikliği karşısında dirençlilik sadece küresel ve ekolojik olmasının ötesinde kentler için de önemli bir kavram haline gelmiştir. IPCC (2012) aşırı olayları yönetme konusundaki özel raporunda (Managing the Risks of Extreme Events and Disasters to Advance Climate Change Adaptation) afet riskini, tehlike, maruz kalma ve kırılganlığın bir kombinasyonu olarak görmektedir. İklim değişikliği, aşırı hava olayları, biyofiziksel ve sosyo-ekonomik hassasiyet risklerinde kentsel ortamların başarısız adaptasyon sağlaması iklim ile bağlantılı afetlere neden olmakta, adaptasyonun başarılı olması kentsel dirençliliği ortaya çıkarmaktadır. Şekil 1'de iklime bağlı afetler ve kentsel çevrelere ilişkin risklerin diyagramı gösterilmektedir (Torabi, 2017: 19).

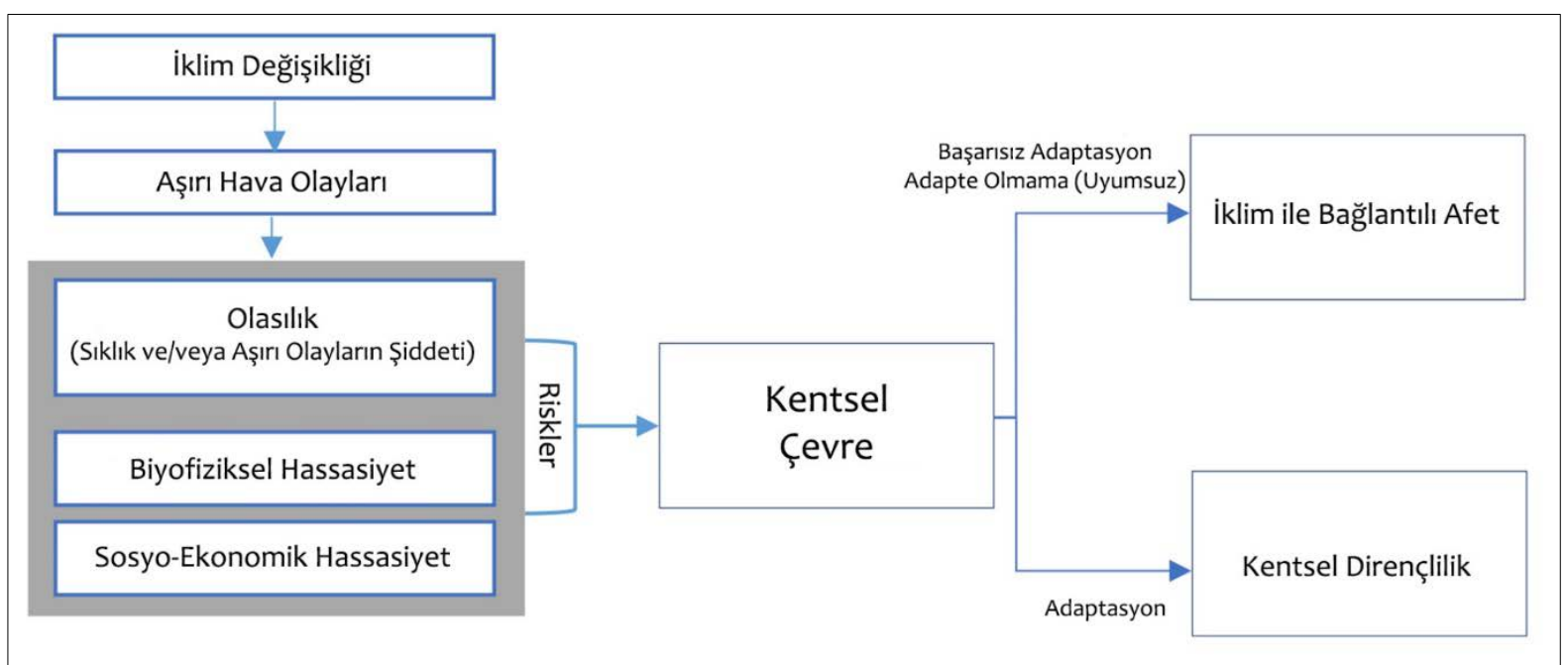

Şekil 1. İklime bağlı afetler ve kentsel çevrelere ilişkin riskler (Torabi, 2017: 19)

\section{DIRENÇLILIKK VE KENTSEL DİRENÇLILİK}

Dirençlilik kavramı, ekolojik literatürde ortaya çıkan ve daha sonraları ise kentsel bağlam ile ilişkilendirilen bir kavrama dönüşmüştür. Dirençlilik (resilience), kökeni biyoloji ve ekosistem bilimlerinden oluşan daha sonraları başka boyutları da ele alınarak tanımlanan teknik bir terimdir. Holling (1973) dirençliliği "sistemlerin kalıcılığının ve değişimin ve rahatsızlığın emilebilme yeteneklerinin ölçülmesi ve yine de popülasyonlar veya durum değişkenleri arasındaki aynı ilişkileri sürdürmesi” olarak tanımlamıştır (Holling, 1973: 14). Holling (1973) kavramı ekosistemler açısından ele alarak var olan bir sistemin değişim/dönüşüm karşısında devamlılığını sürdürmesinin bir ölçütü olarak ifade etmiştir. Holling'in açıklamalarından sonra, dirençlilik kavramı sosyal bilimler tarafından ödünç alınmıştır. Kültürel ekolojiye göre, toplumsal sistemlerin ekolojik sistemlere benzemesinden kaynaklı toplumların işleyişini anlamak için ekolojik sistemlerin ilkeleri uygulanabilir bakış açısı getirilmiştir. Bu düşünce çizgisi psikoloji, coğrafya, sosyoloji ve planlama çalışmalarına da yaygınlaşmıştır. Dirençlilik tanımlarının önemli ortak unsurları vardır; kentler, topluluklar, haneler, kuruluşlar veya işletmeler tarafından bir kapasite. Bu kapasiteler, belirli olaylarla (stresler, tehlikeler, felaketler) veya bunların meydana gelme intimaliyle (riskler) ilgili olarak direnme, absorbe etme, uyarlama, dönüştürme, değiştirme, geri kazanma ve hazırlama gibi belirli eylemleri içermektedir (OECD, 2018; 10).

İklim değişikliği adaptasyonu, sürdürülebilirlik, afet riskini azaltma ve önleme, yoksulluğu azaltma ve küresel sorunlarla başa çıkma anlamında dirençliliğin çok çeşitli uygulamalarına ve bağlamlarına rağmen, evrensel olarak kabul edilen bir terim olamamış, afet riskinin 
azaltılması, iklim değişikliğine adaptasyon, insani yardım gibi alanlar için bile evrensel olarak kabul edilmiş ortak bir tanım oluşamamıştır (aynı şekilde, devletlerin ve örgütlerin dirençliliğe ilişkin görüşleri de farklılık taşımaktadır). Buna rağmen, bu kavramlar ve yaklaşımlar sürekli değişmekte ve tartışmalı olsa da, genelde ortak temalar etrafında uzlaşılmaktadır: Artan insan nüfusuyla nasıl başa çıkabiliriz, hatta nasıl hayatta kalabiliriz? (Leichenko, 2011; Elmqvist, 2014; Meerow, Newell and Stultz, 2016).

Özellikle iklim değişikliği karşısında dirençlilik sadece küresel ve ekolojik olmasının ötesinde kentler için de önemli bir kavram haline gelmiştir. Kentsel alanlar dünya nüfusunun çoğunluğunu barındırması ve kaynak tüketimine neden olmasından dolayı hem teoride hem de pratikte "dirençlilik" için laboratuvarlar haline gelmiştir. Kentlerin dirençliliğinden bahseden ve "Dirençli Kent" olma etiketi ile ortaya çıkan kentsel dirençlilik kavramı hakkında son yıllarda birçok disiplinde çeşitli araştırmalar yapılmıştır. 21.yy itibariyle, "dirençliliğin" anlamları ve tanımları artmakta ve değişmektedir. Fakat bu tanımlamaların hepsi kesin veya özgün değildir. Bu hızlı türeme, uzmanların "terimin iyi tanımlanmadığını, mevcut tanımların tutarsız ve az gelişmiş olduğunu" doğrulamasını göstermiştir (Meerow, Newell and Stults, 2016: 38). Uluslararası bazı kurum ve kuruluşlar tarafından "kentsel dirençlilik" üzerine yapılan tanımlamalar Tablo 1'de gösterilmektedir.

Tablo 1. Kentsel dirençliliğin tanımı (Definitions of urban resilience)

Kurum Tanım

\begin{tabular}{|l|}
\hline UN-Habitat \\
\hline International Council \\
for Local \\
Environmental \\
Initiatives \\
(ICLEI)
\end{tabular}

United Nations Office for Disaster Risk Reduction (UNISDR)

Rockefeller Foundation

Resilientcity.Org

World Bank

USAID

100 Resilient Cities Herhangi bir kentsel sistemin birden fazla şok ve strese dayanma, hızla iyileşme ve hizmetin sürekliliğini sağlama yeteneği.

Temel işlevlerini, yapılarını ve kimliğini korurken, sürekli değişim karşısında uyum ve gelişmeyi sürdürürken, herhangi bir şok veya stresi emip almaya hazır bir kent. Dirençliliği oluşturmak, tehlike risklerini tanımlamayı ve değerlendirmeyi, kırılganlığı ve maruz kalmayı azaltmayı ve son olarak da, direnci, uyarlanabilir kapasiteyi ve acil durum hazırlığını arttırmayı gerektirir.

Tehlikelere maruz kalan bir sistemin, topluluğun veya toplumun, bir tehlikenin etkilerine zamanında ve etkili bir şekilde, temel yapılarının korunması ve restorasyonu da dahil olmak üzere, zamanında ve etkili bir şekilde direnme, absorbe etme, uyum sağlama, dönüştürme ve geri kazanma yeteneği.

Bireylerin, toplulukların ve sistemlerin stres ve şoklar karşısında hayatta kalma, uyum sağlama ve büyüme ve hatta şartlar gerektirdiğinde dönüşüm yapma kapasitesi.

Gelecekteki şokları emmeye ve sosyal, ekonomik ve teknik sistemlerine ve altyapılarına esasen aynı işlevleri, yapıları, sistemleri ve kimliği koruyabilmeleri için baskı yapmasına yardımcı olacak kapasiteler geliştirmiş kent.

İşlevlerini korurken, insanların, toplumların ve ülkelerin olumsuz şoklardan kurtulma yetenekleri.

İnsanların, hane halklarının, toplulukların, ülkelerin ve sistemlerin, şokları ve stresleri kronik kırılganlığı azaltacak ve kapsayıcı büyümeyi kolaylaştıracak şekilde hafifletme, uyarlama ve onlardan kurtarma kabiliyeti.

Bir kentteki bireylerin, toplulukların, kurumların, işletmelerin ve sistemlerin, ne tür kronik stres ve akut şoklara maruz kaldıklarına bakılmaksızın hayatta kalma, uyum sağlama ve büyüme kapasiteleri.

Etkilerinden, sıklığından veya büyüklüğünden bağımsız olarak, kentsel sistemler, topluluklar, bireyler, kuruluşlar ve işletmelerin iyileşme, işlevlerini sürdürme ve bir şok ya da stresin ardından gelişme kapasitesi.

Global Alliance for Resilience (AGIR)

Korunmasız hanehalklarının, ailelerin, toplulukların ve sistemlerin belirsizlik ve şok riski ile karşı karşıya kalma, şoklara etkili bir şekilde dayanma ve bunlara cevap verme ve sürdürülebilir bir şekilde iyileşme ve uyum sağlama kapasitesi.

Kaynak: ICLEI, 2015; Resilient Europe, 2016; Jha, Miner and Stanton-Geddes vd., 2013; AGIR Global Alliance for Resilience, 2016'dan aktaran OECD (2018: 10).

Dirençli kentlerin odak noktasını; sürdürülebilirliği sağlamak, kaynakları etkin ve verimli kullanmak ve kent ile sistemlerin uyumluluğunu sağlamak oluşturmaktadır (Kundak, 2017; Karahan 2018). Tablo 1'deki kavramsal çerçeve, dirençli kentlerin geliştirilmesinde gerekli 
olan temel morfolojik bileşenleri de içermektedir. Kentsel dirençliliğin kavramsal çerçevesinden dirençliliğin ölçütleri ve etkileri sosyal, ekonomik ve çevresel dirençliliği etkileyen temel özellikler ile Tablo 2'de yer almaktadır. Tablodan görüldüğü gibi, bu kriterler su ve enerji verimliliğinden topluluktaki sosyal ilişkilere kadar çok çeşitli konuları kapsamaktadır. Bu kriterler, plancıların ve karar vericilerin, dirençlilik açısından bilgi edinmelerine yardımcı olmaktadır (Soofi-Siavash, 2016: 31).

Tablo 2. Dirençliliğin ölçütleri ve etkileri (Kentsel dirençlilik kavramsal çerçevesinden)

\begin{tabular}{|c|c|c|}
\hline Sosyal & Çevresel & Ekonomik \\
\hline $\begin{array}{l}\text { - Sosyal Dayanışma } \\
\text { - Yer kimliği } \\
\text { - Sosyal aktivite } \\
\text { - Doğal gözetim } \\
\text { - Kamusal alan }\end{array}$ & $\begin{array}{l}\text { - Yürünebilirlik } \\
\text { - Peyzaj Mimarlığı } \\
\text { - Yeşil ve mavi ağ } \\
\text { - Açık alanlar }\end{array}$ & $\begin{array}{l}\text { - Bağlantılar / erişilebilirlik } \\
\text { - İş yerlerine yürünebilirlik } \\
\text { - Taşımacılık fırsatları }\end{array}$ \\
\hline $\begin{array}{l}\text { - Duyusal deneyim } \\
\text { - Fiziksel / zihinsel sağlık } \\
\text { - Sosyal Dayanışma } \\
\text { - Kamusal alan }\end{array}$ & $\begin{array}{l}\text { - Artan biyoçeşitlilik } \\
\text { - Doğal ve yapılı çevrenin } \\
\text { bütünleştirilmesi } \\
\text { - Sürdürülebilir kentsel drenaj } \\
\text { sistemlerini teşvik etmek } \\
\text { - Geliştirilmiş hava kalitesi ve } \\
\text { mikro iklimlendirme }\end{array}$ & $\begin{array}{l}\text { - Artan arazi piyasası değeri } \\
\text { - Verimli arazi kullanımına erişim } \\
\text { - Enerji verimliliği } \\
\text { - Düşük ısı adası etkileri }\end{array}$ \\
\hline $\begin{array}{l}\text { - Sokak hayatı } \\
\text { - Aktif / doğal gözetim } \\
\text { - Çeşitlilik ve sosyal uyum } \\
\text { - Aktif geçiş }\end{array}$ & $\begin{array}{l}\text { - Mikroiklim sorunlarını giderir } \\
\text { - TOD'u tanıma } \\
\text { - SUDS içerir } \\
\text { - Kaliteli (yeşil) tasarım }\end{array}$ & $\begin{array}{l}\text { - Verimlilik ve yenilikte artış } \\
\text { - Altyapı maliyetlerinde azalma } \\
\text { - TOD'u tanıma }\end{array}$ \\
\hline $\begin{array}{l}\text { - Hizmetlere ve eğitime } \\
\text { erişim } \\
\text { - Çeşitlilik ve sosyal uyum } \\
\text { - Yer kimliği } \\
\text { - Sokak hayatı,yürünebilirlik }\end{array}$ & $\begin{array}{l}\text { - Yakınlık ve yeşil/mavi ve açık } \\
\text { alana erişim }\end{array}$ & $\begin{array}{l}\text { - Artan ekonomik faaliyet } \\
\text { - Çeşitlilik ve kullanımların } \\
\text { karışımı } \\
\text { - Küçük/yerel işletmeleri } \\
\text { destekler } \\
\text { - Çok amaçlı geziler }\end{array}$ \\
\hline
\end{tabular}

Kaynak: Soofi-Siavash, 2016: 31

\section{METEOROLOJIK AFETLERE KARŞI DİRENÇLİ PLANLAMA ANLAYIŞI}

TDK tarafından "doğal afet", "insan eliyle önlenemeyen sel, fırtına, deprem, dolu vb. felaketlerin her biri” olarak tanımlanmaktadır (TDK, 2018). Türkçe Bilim Terimleri Sözlüğü tarafından "meteorolojik afet, "sıcaklık, yağış, gibi atmosferik olayların yol açtığı sel, don, buzlanma, dolu, sıcak ve soğuk hava dalgası, orman yangınları, hava kirliliği, çığ, yıldırım, tayfun, tipi, hortum, kuraklık gibi doğa kaynaklı afetler" olarak tanımlanmaktadır (TBTS, 2018). Doğal afetlerin büyük bir kısmını meteorolojik afetler diğer bir ifadeyle meteorolojik karakterli doğal afetler oluşturmaktadır. Son yıllarda iklim değişikliğinin etkilerinin artması ile meteorolojik afetler giderek artmakta ve farklı yerlerde şiddeti, sıklığı ve süresi etkili bir şekilde meydana gelmektedir (Kahraman, 2018; 78). Ortaya çıkan bu tür afetlere karşı yerleşmelerde yaşam kalitesini ve iklim direncini artırmak amacıyla kentlerin dirençlilik göstermesi gerektiği önemli bir konu haline gelmiştir.

İklim değişikliğine karşı kentsel dirençliliği artıracak altyapı geliştirmek için kamu-özel ortaklıkları kullanmak, giderek artan yoğun kuraklıklardan, şiddetli taşkınlardan ve diğer çevresel faktörlerden etkilenen ülkeler için umut verici bir seçenek haline gelmiştir. Bir kentin dirençliliği, mevcut planlama süreçlerinden bazılarını etkinleştirebilir veya kısıtlayabilir. Tüm bu ilişkiler kentsel dirençlilik tartışmasında önemli olsa da, kentsel planlama ile dirençlilik 
arasındaki bağlantıları kentsel çevre ajanlarına, kurumlarına ve sistemlerine odaklanarak anlamak, kentsel afetlere karşı kentsel dayanıklılı̆ı geliştirmek için kritik öneme sahiptir (Torabi, 2017: 33).

"Riskleri oluşturan tehlikelerin önceden belirlenmesi ve zarar görebilirlik düzeyinin tespitine yönelik kentsel risk değerlendirme çalışmalarını içeren bir mekânsal planlama yaklaşımı, olası afetlerin olumsuz sosyal ve ekonomik etkilerini azaltabilmektedir. Kentlerde oluşan tehlike ve risklerin olumsuz etkilerinin azaltılabilmesi, risk yönetimi faktörlerinin kent yapılanmasına titizlikle uygulanması ile mümkün olacaktır. Tam da bu noktada, afete dirençli planlama yaklaşımının önemi ortaya çıkmaktadır" (IPKB ve AFAD, 2014: 10).

Değişim, dinamizm, belirsizlik, uyumluluk ve öz-örgütlenme dirençli planlamanın çekirdeğini oluşturmaktadır. Dirençlilik düşüncesinin kentsel planlama teorisi ve pratiğine entegre edilmesi, kentsel sistemlerde iklim değişikliği nedeniyle ortaya çıkan belirsizlik ve karmaşıklıkları anlamak için gereklidir (Albers and Deppisch, 2013). Dirençliliğe dayalı planlama, kentsel sistemin dinamiklerini kabul etmeli, geleneksel planlamadan uzaklaşmalı ve izleme, değerlendirme ve senaryo oluşturma süreçlerinin düzenli ve yinelemeli süreçlerini içeren uyarlamalı planlamaya geçmelidir. Ayrıca, "dirençliik-temelli" bir planlamanın elde edilmesi için "komut ve kontrol" yaklaşımlarından aşağıdan yukarıya yaklaşımların ve sosyal öğrenme uygulamalarının tanınmasına yönelik bir paradigma kaymasının gerekli olduğu da ortadadır (Sharifi and Yamagata, 2018). Geleneksel planlama ve dirençli planlama arasındaki ayrım için Sharifi and Yamagata (2018) tarafından tematik alanlarda (afet risk yönetimi, planlama vizyon ve stratejileri, halkın katılımı ve kapasite geliştirme, eşitlik sağlamak ve yoksul ve marjinalleşmiş toplulukları güçlendirmek, geleneksel yerel bilgiden öğrenmek, kurumsal reformlar, sektörel, mekansal ve zamansal bağlantılar, dirençli arazi kullanım planlaması, dirençli kentsel altyapı) yapılan tartışmaların bir özeti Tablo 3'te verilmiştir.

Tablo 3. Planlamaya yönelik geleneksel ve dirençli yaklaşımların temel özellikleri

\begin{tabular}{|c|c|c|}
\hline Planlama Temaları & Geleneksel & Dirençli \\
\hline Afet Risk Yönetimi & $\begin{array}{l}\text { Kısa ve orta vadeli acil durum planlama } \\
\text { ve azaltma çabalarına odaklanma. } \\
\text { - Hızlı değişkenleri, kaotik ve ani } \\
\text { değişiklikleri hedefleme. } \\
\text { - } \quad \text { Statik güvenlik açığını değerlendirme. }\end{array}$ & $\begin{array}{l}\text { - } \quad \text { Orta-uzun vadeli yaklaşım. } \\
\text { - } \quad \text { dem ani, hem de yavaş ve sürekli } \\
\text { değişimleri gidermek için uygun. } \\
\text { - } \quad \text { Dinamik ve karmaşıklıkların önemini } \\
\text { tanımak ve zamansal ve mekansal } \\
\text { ölçekler arasındaki dönüşümleri } \\
\text { değerlendirme. } \\
\text { - Sürekli değişen risklere cevap verme } \\
\text { ve sistemin cevap marjlarını ve } \\
\text { kapasitelerini arttırma kapasitesi. }\end{array}$ \\
\hline $\begin{array}{l}\text { Planlama Vizyon } \\
\text { ve Stratejileri }\end{array}$ & $\begin{array}{l}\text { - } \quad \text { Lineer ve statik detaylı planlama. } \\
\text { - } \quad \text { Riski ortadan kaldırmayı vurgulayan } \\
\text { mühendislik yaklaşımları. } \\
\text { - } \quad \text { Felaket kurtarma için denge yaklaşımı. } \\
\text { - } \quad \text { Yaklaşımı tahmin etme ve önleme. }\end{array}$ & $\begin{array}{l}\text { - Uyarlanabilir planlama (düzenli ve } \\
\text { tekrarlamalı izleme ve senaryo } \\
\text { oluşturma süreçleri). } \\
\text { - Gelecekteki koşulların } \\
\text { öngörülemezliğini ve riskleri tamamen } \\
\text { önlemedeki zorlukları kabul etme. } \\
\text { - } \quad \text { Sistem işlevselliği ve olağanüstü durum } \\
\text { kurtarma için farklı bakış açıları. }\end{array}$ \\
\hline $\begin{array}{l}\text { Halkın Katılımı ve } \\
\text { Kapasite } \\
\text { Geliştirme }\end{array}$ & $\begin{array}{ll}\text { - } & \text { Çevresel determinizm. } \\
\text { - } & \text { Sınırlı halk katılımı. } \\
\text { - } & \text { Yerel makamların hizmet sunmaktan } \\
& \text { sorumlu olması (komuta ve kontrol). }\end{array}$ & $\begin{array}{l}\text { - Insan odaklı tasarım (insanları } \\
\text { planlama çabalarının merkezine } \\
\text { koyarak). } \\
\text { - Ortak tasarım, ortak yapım ve ortak } \\
\text { uygulama. } \\
\text { - Toplumsal faaliyetlerin ve kendi kendini } \\
\text { organize etmenin önemi (kapasite } \\
\text { geliştirme). }\end{array}$ \\
\hline $\begin{array}{l}\text { Eşitlik Sağlamak } \\
\text { ve Yoksul ve }\end{array}$ & $\begin{array}{l}\text { - Düşük gelirli kentsel alanların } \\
\text { şartlarının iyileştirilme koşullarında }\end{array}$ & $\begin{array}{l}\text { - Sosyal adaleti dirençli planlama } \\
\text { çabalarına entegre etme. }\end{array}$ \\
\hline
\end{tabular}




\begin{tabular}{|c|c|c|}
\hline $\begin{array}{l}\text { Marjinalleşmiş } \\
\text { Toplulukları } \\
\text { Güçlendirmek }\end{array}$ & $\begin{array}{l}\text { başarısızlık. } \\
\text { - Zengin yerleşim bölgelerinin kentlerde } \\
\text { ortaya çıkışı ve yayılması. } \\
\text { - Riskli bölgelerdeki gelişimde kontrolün } \\
\text { kaybedilmesi. } \\
\text { - Yoksul mahallelerde mülklerin sınırlı } \\
\text { sigortası. }\end{array}$ & $\begin{array}{l}\text { - Kentsel eşitsizliklerin azaltılması } \\
\text { (örneğin uygun fiyatlı konut politikaları } \\
\text { yoluyla). } \\
\text { - } \quad \text { Riskli bölgelerde gelişmeyi düzenleme. } \\
\text { - } \quad \text { Yer değiştirmenin, toplulukların geçim } \\
\text { olanaklarını etkilememesini sağlama. } \\
\text { - } \quad \text { Mülkiyet duygusunu güçlendirme ve } \\
\text { geliştirme. } \\
\text { - Yenilikçi belediye sigortası planlarından } \\
\text { yararlanım (örneğin toplu sigorta ve } \\
\text { tasarruf planları). }\end{array}$ \\
\hline $\begin{array}{l}\text { Geleneksel Yerel } \\
\text { Bilgiden } \\
\text { Öğrenmek }\end{array}$ & $\begin{array}{l}\text { - } \quad \text { Modern planlama ve tasarım } \\
\text { stratejilerine aşırı güvenme. } \\
\text { - } \quad \text { Standart bina tekniklerinin kullanımı. }\end{array}$ & $\begin{array}{l}\text { - Geleneksel başa çıkma kapasitelerine } \\
\text { dikkat etme. } \\
\text { - Yerel mimari ve yerel bina } \\
\text { teknolojilerinin farkındalığı. }\end{array}$ \\
\hline $\begin{array}{l}\text { Kurumsal } \\
\text { Reformlar }\end{array}$ & $\begin{array}{l}\text { - } \quad \text { Sektörel planlama. } \\
\text { - } \quad \text { Teknik dil kullanarak iletişim kurma. } \\
\text { - } \quad \text { Kenarıdan aşağıya planlama. } \\
\quad \text { yatırımın sınırılıöınetiminde özel (özellikle } \\
\\
\text { gelişmekte olan ülke). }\end{array}$ & $\begin{array}{ll}\text { - } & \text { Sektörler arası etkileşimler (birbirine } \\
\text { - } & \text { bağlı ve bağımlılıklar). } \\
\text { - } & \text { İşbirliği kültürünün teşviki. } \\
\text { - } \quad \text { Şeffaf karar verme süreci. } \\
\text { - } \quad \text { Yaygın olarak anlaşılabilir bir dil } \\
\text { kullanarak iletişim. } \\
\text { - } \quad \text { Güçlü kamu-özel ortaklıkları. }\end{array}$ \\
\hline $\begin{array}{l}\text { Sektörel, } \\
\text { Mekansal ve } \\
\text { Zamansal } \\
\text { Bağlantılar }\end{array}$ & $\begin{array}{l}\text { - Farklı sektörler ve boyutlar arasındaki } \\
\text { bağlantıların ele alınamaması. } \\
\text { - Mekansal ve zamansal dinamikleri } \\
\text { anlama eksikliği. }\end{array}$ & $\begin{array}{l}\text { - Farklı sektörler arasındaki bağlantıları } \\
\text { anlama çabaları. } \\
\text { - Mekansal ve zamansal dinamikleri } \\
\text { anlamayı vurgulama. }\end{array}$ \\
\hline $\begin{array}{l}\text { Direçli Arazi } \\
\text { Kullanım } \\
\text { Planlaması }\end{array}$ & $\begin{array}{l}\text { - Ekolojik olarak hassas bölgelerin } \\
\text { korunmasında sınırlı başarı. } \\
\text { - İşlevsel bölgeleme. }\end{array}$ & $\begin{array}{ll}\text { - } \quad \text { Kkosistem koruması. } \\
\text { - } \quad \text { Yoğuna kullanım geliştirme. } \\
\text { geçirgenlik ve çoklu işlevsellik gibi } \\
\text { diğer özelliklere de dikkat etme. }\end{array}$ \\
\hline $\begin{array}{l}\text { Dirençli Kentsel } \\
\text { Altyapı }\end{array}$ & $\begin{array}{l}\text { - Sağlamlığa aşırı güven. } \\
\text { - } \quad \text { Büyük, merkezi altyapı. }\end{array}$ & $\begin{array}{l}\text { - Çeşitlilik, artıklık, esneklik, verimlilik, } \\
\text { modülerlik ve yenilikçilik gibi diğer } \\
\text { özellikleri tanıma. } \\
\text { - } \quad \text { Küçük ölçekli, merkezi olmayan altyapı. }\end{array}$ \\
\hline
\end{tabular}

Kaynak: Sharifi and Yamagata, 2018

Özetle, geleceğin yaşamsal odaklarında afetlerden etkilenebilirliliği en aza indirmek için "dirençli kentler, dirençli yerleşmeler, dirençli yapılar vb." yaklaşımlar ile çözüm arayışlarına gidilmeye çalışılmaktadır. Tablo 3'de dirençli planlamanın temel özellikleri de ele alınırsa, kısaca dirençli planlama anlayışı, afetlerde meydana gelebilecek hasarlara karşı yerleşmelerin dirençlilik göstererek, yıkıcı etkilerden en az hasarla çıkması için yaşam odaklarında üst ölçeklerden başlayan, alt ölçeklere kadar inen, kademeli birlikteliğin sağlandığı, bütüncül ve stratejik bir planlama yaklaşımını içermektedir.

\section{METEROLOJIK AFETLERE KARŞI DİRENÇLİ PLANLAMAYA ÖRNEKLER}

Geçmişte binlerce insanın bulunduğu yaşam odakları doğal ve insan kaynaklı nedenlerden dolayı zarar görürken, artık günümüzde iklim kaynaklı afetler nedeniyle yaşam odakları büyük yıkıma uğramaktadır. İklim kaynaklı bu afetler konut faaliyetlerini etkilemiş ve kent bütçeleri üzerinde benzeri görülmemiş etkiler ortaya koymuştur. Buna çözüm üretmek amacıyla ortaya çıkan iklim adaptasyonu, aşırı yağmur olaylarının neden olduğu sel baskınları da dahil olmak üzere, iklim değişikliğinin sonuçlarının getirdiği riskleri azaltmaya çalışmaktadır. Son zamanlarda, yaşam odaklarında dirençliliği artırma konusunda giderek daha fazla endişe duyulmaktadır. Bu nedenle dünyanın farklı ülkelerinde meteorolojik afetlere karşı dirençli planlama ile dirençli kent olma yolunda ilerleyen birçok kent vardır. Bu planlama örneklerinden bazılarının yaptığı politika, stratejiler Tablo 4'de yer almaktadır. 


\section{Tablo 4. Meterolojik afetlere karşı dirençli planlamaya örnekler}

Katalonya'da iklim değişikliğinin en hassas bölgesi, su baskını ve deltanın çökmesi açısından Ebro Deltasıdır. Riumar Kent Planı, bölgedeki turistik tesislere (otel ve daire) ayrılan 499 konut

Ebro Delta

Nehri'ndeki Riumar Kent

Planı, Katalonyaİspanya ve $11.000 \mathrm{~m}^{2}$ Ilik alanın inşaatının oldukça hassas olduğunu belirtmektedir. Riumar Kent Planı, Katalan İklim Değişikliği Dairesi'nin, bölgenin kırılganlık derecesi konusunda uyardığı ve denizin ilk hattı üzerinde bu evlerin inşası için insanlara ve malzemelere yönelik sel risklerinin olduğuna dair stratejik çevresel değerlendirme sürecine girmiştir. Riumar Kentsel Plan Çevresel Değerlendirme sürecinde, iklim değișikliği analizinde önceliğin belirlenmesine, savunmasızlığın azaltılmasına ve dayanıklılığın artırılmasına yönelik gerçekleştirilecek en önemli eylemler tanımlanmıştır. Özellikle, çevre raporu, deniz hattından 100 metre uzaklıktaki yapıları geri alma yükümlülüğü getirmiştir.

\section{Yağmur Suyunu Emen Iklim Caddesi, Kopenhag, Danimarka}

\section{Taşkın \\ Koruma \\ Stratejisi için \\ Hidrolik \\ Modeller, \\ Prag, Çek \\ Cumhuriyeti}

\section{Kopenhag'ın \\ ilk Iklim \\ Dirençli \\ Semti, \\ Kopenhag}

Projesi,

Singapur

Kentler için

Bir Çerçeve:

Yeşil Odaklı

Uyarlama

Projesi, İzmir
Aşırı yağışların yol açtığı taşkınlardan kaçınmak amacıyla, Kopenhag sokaklarından biri olan Helenevej, yağmur suyunun sızmasıyla bir iklim sokağına dönüştürülmüştür. Yağmur suyunun yüzeyden sızmasına izin vermek için asfalt su geçirimli yüzeylere dönüştürülmüş (döşenen fayans arasındaki boşluklar suyu yol yüzeyinin altına taşır), böylece yağmur suyu yeraltı suyu akiferlerine giderek süzülmüştür. Karoların altında $40 \mathrm{~cm}$ çakıldan oluşan rezervuar alanlar oluşturulmuş, aşırı yağış durumunda, suyun yüzeyin altındaki haznede tutulması sağlanmıştır. Caddenin aşırı yağış olması durumunda problemsizce büyük su hacimlerini idare edebileceği kanıtlanmıştır.

1997'deki şiddetli bir selden sonra, Cek hükümeti bir taşkın koruma stratejisi benimsemiştir. Prag şehir merkezi ve banliyöler için acil durum planları, model sonuçlarına göre güncellemiş, taşkın savunma sistemindeki en zayıf noktalar tespit edilerek iyileştirme önerileri değerlendirilmiştir. Bu analizlere dayanarak, Eski Şehir için taşkın korumanın ilk aşaması 2001 'de tasarlanmış ve uygulanmıştır. Sadece bir yıl sonra, 2002'de Prag, tarihin en kötü selini yaşamıştır. Geliştirilen model ile Tarihî Eski Kent'i korumanın yanı sıra hayat kurtarmak için doğru yer ve zamanda mobil engelleri kapatmayı başarabilmişlerdir. Model o zamandan beri düzenli olarak yeniden değerlendirilip güncellenmiştir ve $A B$ Taşkın Direktifi'nin gerektirdiği risk haritalarının çizilmesi de dahil olmak üzere, tüm taşkın koruma sisteminin yanı sıra kentsel planlamada da kullanılmıştır.

Kopenhag'ın çoğunun aksine, Skt. Kjelds Kvarter bir yamaçta oturmakta ve limana doğru eğilmektedir. Bu nedenle asıl amaç, yüzey suyunu bölgede tutmak ve mümkün olan en fazla yer altı suyu için yağmur suyunu sızdırmaktır. Yağmur yağarken depolama kapasitesi kullanılmıştır. Aşırı yağışlar sırasında fazla su mahalleden uzağa, hasar riskinin en aza indirildiği yerlere taşınmıştır. Mahallenin genel amacı, günlük yağmuru yerel olarak yönetebilen esnek yüzey çözümlerine sahip olmaktır. Aşırı yağışlar sırasında, yüzey çözümleri, yağmur suyunun en yakın limana kontrollü bir şekilde taşınmasını sağlayan geleneksel bir split yağmur suyu kanalizasyon sistemi ile birleştirilmiştir.

Bishan Park Projesi, ülkenin su kütlelerini drenaj ve su temini işlevlerinin ötesinde, rekreasyon için yeni alanlar içeren göllere dönüştürmek için yapılan büyük projelerden biridir. Kallang Nehri'nde, kentleşme nedeniyle havzadan kaynaklanan artan yağmur suyu akıntılarını karşılamak için iyileştirme yapılmış, $2.7 \mathrm{~km}$ uzunluğundaki düz beton drenaj kanalı, kıvrımlı, doğal bir nehre dönüştürülmüş ve nehir sisteminin dinamik sürecine uyum sağlamak için 62 hektarlık park alanı yeniden düzenlenmiştir. Doğallaştırılmış nehrin parka girmesinden bu yana, parkın biyolojik çeşitliliği \%30 artmıştır.

Proje kapsamında İzmir Büyükşehir Belediyesi bölgesi içinde sert hava olaylarının ileriye dönük tahmini ile ilgili 2050 ve 2100 için iklim değişikliği modellerinin analizi yapılmıştır.

-Pilot alan içinde, kentsel yeșil altyapı ve modelleme arazi kullanımı haritalandırılmış, -Pilot alanda kantitatif teknikler kullanarak düzenleyici kentsel ekosistem hizmetlerini (ES) hesaplama ve haritalama yapılmış,

-Farklı arazi kullanımında zayıflıkları analiz etmek ve pilot alan içinde kentsel dayanıklılığı arttırmak için duruma duyarlı önerilerde bulunulmuş,

-Yeşil altyapı aracılığıyla kentsel dayanıklııı̆ın sağlandığı en iyi uygulama alanlarına çalışma ziyareti organize edilmiş,

-Yapılan analiz sonucu kılavuz hazırlanmıs,

-Belediye mensupları, yararlanıcı gruplar için seminerler ve çalıştaylar organize edilmiştir. 


\section{SONUÇ YERINE}

Son yıllarda, küresel ölçekte devletler, politikacılar ve bilim insanları iklim değişikliğinin kentler için yarattığı sorunlara karşı daha fazla farkında olmaya başlamıştır. Çünkü, gelecek senaryolara göre iklim değişikliğinin daha yüksek sıcaklıklar, deniz seviyesi artışı, şiddetli fırtınalar, kuraklıklar ve sıcak hava dalgası getirmesi olasıdır. Ayrıca iklim değişikliği, beraberinde kentsel tehditleri de getirmektedir. Dahası, son zamanlarda meteorolojik afetlerin yaşam maliyetlerini nasıl azalttığı, kentsel alanları ve toplulukları nasıl tahrip ettiği birçok örnekte görülmektedir. Bu tehditlerin riskini ve etkisini azaltmak, yerleşimlerin güvenliğini ve refahını artırmak için kentsel ölçekli tehditleri ele almak için daha dirençli ve hazırlıklı olunması gerektiği açıkça görülmektedir.

İklim kaynaklı afet zararlarını kabul edilebilir riskler düzeyinde tutabilmek ve yaşam odaklarında oluşabilecek hasarları önceden tahmin edebilmek için afet öncesi yapılması gereken çalışmaların en başında, fiziki planların afetlere direnç gösterecek şekilde uyumlanabilir bir yapıya büründürülmesi gerektiği üzerinde sıklıkla durulmaktadır. Küresel ölçekte dirençli kent olma yolunda ilerleyen birçok kentsel alan vardır, fakat bu çalışmalar gelecekte oluşacak felaketlere cevap verecek kadar yeterli değildir. Çünkü incelenen çalışmalar parçacıl olarak ele alınmakta ve dirençli planlamanın bir parçası olan bütüncül planlama yaklaşımını içermemektedir. Bu nedenle kent yönetiminde yer alan bütün aktörler kentsel dirençlilik kavramını politikaları içerisine dahil etmeli ve dirençli kent oluşturma yolunda stratejik mekânsal, bütüncül ve akıllı ilerlemelidir.

Afet risk yönetimi her zaman kent planlamasının önemli bir parçasıdır. Fakat afet risk yönetimi esas olarak kısa ve orta vadeli acil durum planlama ve azaltma çabalarına odaklanmıştır. Dirençlilik düşüncesinin kentsel afet riskini azaltma ile bütünleştirilmesi, iklim değişikliği gibi olgularla daha uyumlu, orta ve uzun vadeli bir yaklaşım benimseyen dirençli planlama anlayışıyla beraber hareket etmesi gerekmektedir. Bu nedenle ortaya çıkabilecek ani şoklara cevaben, sistemin direncini ve sağlamlığını arttırmak, hasar meydana geldiğinde hızlı bir şekilde iyileşmek için uyarlamalı/dirençli planlar geliştirmek önemlidir.

Riski ortadan kaldırmak yerine, riske maruz kalmaktan kaçınmak (örneğin uygun yer seçimi yoluyla) ve riske karşı dayanıklılığı arttırmak üzerine stratejiler geliştirilmelidir. Bu nedenlerle, geleneksel planlamadan (doğrusal ve statik), değişimi kapsayan ve düzenli, tekrarlamalı izleme, değerlendirme ve senaryo oluşturma süreçlerini içeren uyarlamalı ve dirençli planlama paradigmasına geçilmesi gerekmektedir. Meteorolojik kaynaklı doğal afetlere karşı dirençli planlama ile alınabilecek önlemlerden bazıları şunlardır:

- Afet yönetiminde, kent ve bölge planlama ve diğer disiplinler ile entegrasyon sağlanarak afetler karşısında uyumlanabilir stratejik mekânsal planlar oluşturmak.

- Olası meteorolojik afet senaryoları oluşturmak.

- Risk altındaki alt ve üst yapıların kullanım sınıflandırmasının analizini yapmak, güvenli erişebilirliğini sağlamak.

- Yerleşmeye özgü risk faktörleri belirlemek ve türüne göre risk haritaları üretmek.

- Mekânsal ve zamansal karşılaştırmalar yapmak.

- Afetlere karşı dirençli yaşam odakları için amaçlar/hedefler hiyerarşisi oluşturmak, risk stratejileri belirlemek.

- Alternatif planlar ortaya çıkarmak ve en makul/normatif olanını bulmak. 
- Risk derecelerine göre bölgelemeler oluşturmak.

- Önemli alanlarda yapılaşmanın sınırlandırılması ve o alanda tehlike oluşturmayacak farklı bir işlev kazandırmak.

- Kıyı bölgelerinde akıllı setler oluşturularak deniz seviyesindeki ani yükselme durumlarında setlerin yer altından çıkarak suyun yerleşim bölgelerine ulaşmasını engellemek.

- Yerleşim alanlarında geçirimli yüzeyler oluşturularak yüksek yağışlarda suyun toplanacağı bölgeler oluşturmak.

- Risk altındaki alanlarda bulunan konutlar belirlenerek senaryo yılına göre tahliye etmek ve riskli bölgeleri yağmur bahçelerine dönüştürülmek.

- Güvenli toplanma bölgeleri oluşturmak, oluşturulan toplanma bölgelerinde tahliye stratejileri geliştirmek.

- Ana ulaşım güzergâhları üzerinde afet durumunda kullanılacak olan ambulans noktaları oluşturmak.

- Önemli ulaşım, erişim rotalarını özgün mühendislik yaklaşımları ile dizayn ederek, sel ve taşkınlarda yükseltilebilir yüzeyler elde etmek.

- Bilinen riskleri, intiyaçları ve olası çözümleri belirlemek için planlama sürecinde birden fazla paydaşla birlikte çalışmak

Bunlar gibi önlemler alınması artık bir zorunluluk haline gelmiştir:

Çünkü; Başka Bir Dünya Yok! 


\section{KAYNAKLAR}

AGIR Global Alliance for Resilience, (2013). Regional Roadmap. Adopted On 9 April 2013. https://www.oecd.org/swac/publications/AGIR\%20roadmap_EN_FINAL.pdf.

İBB (İzmir Büyükşehir Belediyesi) ve PAD (Peyzaj Araştırmaları Derneği). (2019). İklim Değişikliğine Dirençli Kentler için bir Çerçeve: Yeşil Odaklı Uyarlama Kılavuzu. Yazarlar: Berberoğlu, S., Çilek, A., Ünlükaplan, Y., PARDUS, İzmir.

Elmqvist, T. (2014). Urban Resilience Thinking. Solutions, 5(5), 26-30. http://www.thesolutionsjournal.com/node/237196.

Holling, C.S. (1973). Resilience and Stability of Ecological Systems. Annual Review of $\begin{array}{lllll}\text { Ecology and Systematics, } & \text { Vol. } & \text { 1-23. }\end{array}$ https://doi.org/10.1146/annurev.es.04.110173.000245.

ICLEI, (2015). ICLEI Resilient Cities Agenda. http://www.iclei.org/activities/agendas/resilientcity.html.

IPCC (Intergovernmental Panel on Climate Change). (2012). Managing the Risks of Extreme Events and Disasters to Advance Climate Change Adaptation. Special Report of Working Groups I and II of the Intergovernmental Panel on Climate Change [Field, C.B., V. Barros, T.F. Stocker, D. Qin, D.J. Dken, K.L. Ebi, M.D. Mastrandrea, K.J. Mach, G.-K. Plattner, S.K. Allen, M. Tignor, and P.M. Midgley (eds.)]. Cambridge, UK and New York, NY, USA: Cambridge University Press.

IPKD (İstanbul Proje Koordinasyon Birimi) ve AFAD (Afet ve Acil Durum Müdürlüğü). (2014). Afete Dirençli Şehir Planlama ve Yapılaşma. Beyaz Gemi Sosyal Proje Ajansı, İstanbul. https://www.ipkb.gov.tr/e-kutuphane/afete-direncli-sehir-planlama-ve-yapilasma_62/.

Karahan, A.Ö. (2018). Dirençli Kentler Bağlamında Karaman Kentinin Değerlendirilmesi. Ankara Üniversitesi, Fen Bilimleri Enstitüsü, Yüksek Lisans Tezi, 270 s, Ankara.

K. Jha, A, W. Miner, T., and Stanton-Geddes, Z. (eds.) (2013). Building Urban Resilience: Principles, Tools and Practice. The World Bank. http://dx.doi.org/10.1596/978-0-82138865-5.

Kahraman, S. (2018). İklim Değişikliğinin Bölgesel ve Kentsel Alanlar Üzerinde Etki Analizi: TR61 (Antalya, Isparta, Burdur) Bölge Örneği. Süleyman Demirel Üniversitesi, Fen Bilimleri Enstitüsü, Yükseklisans Tezi, 169 s, Isparta.

Kundak, S. (2017). Dirençliliğin temelleri. Dirençlilik Dergisi, 1(1), 55-69.

Leichenko, R. (2011). Climate Change and Urban Resilience. Current Opinion in Environmental Sustainability, 3(3), 164-168. http://dx.doi.org/10.1016/j.cosust.2010.12.014Lhomme.

Meerow, S., Newell, J.P., and Stultz, M. (2016). Defining Urban Resilience: A review. $\begin{array}{lllll}\text { Landscape and Urban } & \text { 38-49. }\end{array}$ https://doi.org/10.1016/j.landurbplan.2015.11.011.

OECD, (2018). Indicators for Resilient Cities. OECD Regional Development Working Papers, 2018/02. https://doi.org/10.1787/6f1f6065-en.

Prasad, N., Ranghieri, F., Shah, F., Trohanis, Z., Kessler, E. and Sinha, R. (2009). Climate Resilient Cities-A Primer on Reducing Vulnerabilities to Disasters. The World Bank, 
Washington. http://documents.worldbank.org/curated/en/164671468026943315/Climateresilient-cities-a-primer-on-reducing-vulnerabilities-to-disasters.

Resilient Europe. (2016). Ready for the Future? Urban Resilience in Practice. http://urbact.eu/ready-future-urban-resilience-practice.

Sharifi, A., Yamagata, Y. (2018). Resilience-Oriented Urban Planning. Lecture Notes in Energy, Springer Nature, 65. https://doi.org/10.1007/978-3-319-75798-8_1.

Soofi-Siavash, Y. (2016). Achieving Urban Resilience: Through Urban Design and Planning Principles. Postgraduate Thesis, Department of Planning Oxford Brookes University. https://www.researchgate.net/publication/315676074_Achieving_Urban_Resilience_Through _Urban_Design_and_Planning_Principles.

TDK. (2018).Doğal Afet. http://sozluk.gov.tr/.

Türkçe Bilim Terimleri Sözlüğü (TBTS). (2018). Meteorolojik Afet. http://www.tubaterim.gov.tr/.

Torabi, E. (2017). To Be Beside the Seaside: Urban Resilience to ClimateRelated Disasters in Coastal Cities. Thesis (PhD Doctorate). Griffith University School Of Environment Cities Research Institute Gold Coast Campus. https://experts.griffith.edu.au/publication/n2e1110fa6fb4e00928a4d743348b9d9b.

UNISDR\&CRED. (2015). The Human Cost of Weather Related Disasters 1990-2015. https://www.unisdr.org/files/46796_cop21weatherdisastersreport2015.pdf.

United Nations. (2015). The United Nations World Water Development Report, Water for a Sustainable World. https://unesdoc.unesco.org/ark:/48223/pf0000231823.

WSCTT (World Summit Clımate And Territorıes Towards The COP21). (2015). Inspiring Action for Urban and Regional Planning. Erişim Tarihi: 01.01.2018. 